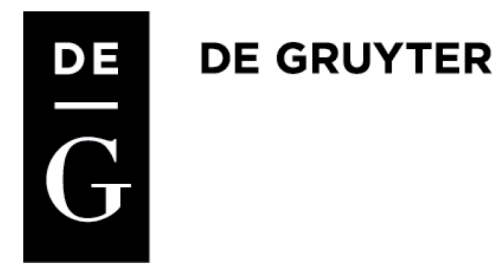

Karol Nawrocki

(The Institute of National Remembrance, Gdańsk branch)

\title{
"AUTOGANGS". CAR SMUGGLE TO COMMUNIST POLAND IN THE 1980s
}

The article refers to the economic consequences of the post-war division of Europe into the capitalist West and communist East. One of the consequences of this division was the creation of peculiar crime phenomenon on the eastern side of the "iron curtain", which consist on exploit the prices and goods availability differences between wealthy West and backward East of Europe. This being the case of illegal movement of goods, begun from the 1940s, between those two worlds. In article you can find the outline of characteristic for the whole Polish "People's" Republic period smuggling conducts. The key subject of following text is first of all the problem of car smuggling in the 1980s, which wasn't researched by polish historians before. In this interesting for us times in Western Europe (West Germany, Austria, France) and in Scandinavia at least few groups of organized crime were active in a areas of car stealing and smuggling a luxury goods into Poland. The essence of following article are the presentation of these groups, their bosses, criminal practices and techniques and indication of the cooperation between polish car smugglers and western countries citizens. Sources for this text are based first of all on operational and investigation records of former Security Service collected in archives of the Institute of National Remembrance.

Keywords: "autogangs", communist Poland, Poland "People's" Republic, organized crime, "Nikoś", smuggling, thief's.

doi:10.1515/sho-2016-0010

\section{INTRODUCTION}

Despite its short, merely 50-year-long history, communist Poland generated a number of mechanisms which, on the one hand, encouraged communist elites to freely gain wealth in the West, but on the other, prompted the underprivileged part of society to engage in criminal activities. Vast disproportions in the quality of life between Eastern and Western Europe, limited access to virtually all goods paid for with foreign currency and 
to the so-called luxury goods, and, finally, the unstable exchange rate of the PLN and the unpredictability of currency reforms introduced by the authorities, became the bedrock of organized, state-driven crime. At the same time, these factors determined the fact that smuggle, as one of the two methods enabling Poles to live dignified lives in the communist state, enjoyed a certain cult throughout the 1944-1989 period, the other method being joining the communist party and becoming a member of the apparatus.

Smuggling gold and all foreign currencies remained the most versatile activity throughout the whole communist Poland period. Goods were smuggled both from and to the West, and between various communist states. However, the underground market also reacted to short-term smuggling trends in Europe. As Jerzy Kochanowski established, on the marine boundaries of communist Poland:

[...] artificial jewelry was in fashion in the years 1950-1960. In the years 1956-1960, these were cosmetics, especially lipsticks. In the years 1958-1966, there was a demand for wristwatches, and in the years 1960-1965, for textiles. In the early 1970s, large-scale smuggle of electronic watches and mini calculators began [Kochanowski J. 2010: 140].

Goods were also smuggled over inland waterways. The main destinations of the Polish fluvial smuggle were the Federal Republic of Germany (West Germany) and West Berlin. Barges were primarily used to transport alcohol and cigarettes, as the prices in the Polish "Pewex" (short for Internal Export Company) and "Baltona" (Foreign Trade Company) shops were much lower, but other products, such as caviar or crystal, were also smuggled this way. Smuggled goods were stored e.g. in the living quarters, kitchens, ballast tanks, as well as cargo holds, where they were covered e.g. with a few tons of coal [Latek A. 1983: 6-7].

The year 1981 was, in a way, a breaking point for the communist smuggle - the number of Poles going to other communist states drastically dropped while the number of journeys to the west of Europe doubled. As Jerzy Kochanowski claims, most short-terms trips had a financial motivation (work or trade). Shrinking supplies in the market and the weakness of the Polish currency meant that gold was the best saving option for Poles. It is estimated that "the private import, to which the authorities turned a blind eye, could consume (in 1981) 310 million dollars. For example, in 1980, 3 tons of gold were transferred to Poland from Great Britain only, according to the estimates of the World Currency Yearbook" [Kochanowski J. 2010: 271]. However, the year 1981, aside from its known consequences 
(martial law and a number of failed economic reforms), was characteristic for one more reason. Until that time smuggle primarily:

[...] played a complementary role. It provided products commonly considered luxurious. However, in the face of a complete failure of the state channels of distribution, it became virtually one of the basic sources of supply (e.g. in cosmetics) [Kochanowski J. 2010: 141].

Both in the 1970s and in the 1980s, the variety of goods smuggled to Poland was not limited to foreign currency, metals, food, and luxury products. As we can read in one academic paper devoted to the subject, apart from currency and miscellaneous products, the main smuggling categories included: works of art, pornography, anti-government materials (underground publications), and people [AIPN (The Archive of the Institute of National Remembrance) Gdańsk, WUSW (Regional Domestic Affairs Office) Gdańsk, 0087/34, vol. 17; Cilecki E. 1987: 55]. In the mid 1980s, drugs (mainly amphetamine, marijuana, and hashish) appeared more often at marine and aerial boundaries [AIPN Gd., KW MO (Regional Citizens' Militia Headquarters) Gdańsk, 0046/258, ff. 98, 108]1. In 1986 and 1987, according to customs officers from around the world (the report quoted included 48 countries working as a part of the Customs Cooperation Council):

[...] they found and confiscated over 9 tons of heroin, 68.5 tons of cocaine, 2300 tons of various intoxicating cannabis-derived products. Apart from that, they prevented the illegal traffic of 26.6 million doses of psychiatric drugs [Latka A. 1990: 17-18].

1 Obviously, drugs were found in communist Poland also in the 1970s, however, they were different (psychiatric medication dominated) and the scale of consumption was smaller than in the next decade. A thorough operational investigation of the hippy and drug addict communities was conducted e.g. in Sopot, the entertainment capital of the so-called Tricity (the three largest cities in eastern Pomerania - Gdańsk, Gdynia, Sopot). The operation, code-named "Mak" ("Poppy"), took place in late May 1972. Almost 70 officers of the Citizens' Militia (MO) and the State Security Office (SB) and over 30 members of Volunteer Reserve Militia (ORMO) and Railroad Guards (SOK) took part. As a part of the operation, bars and restaurants popular among young people and "the suspicious element" were checked (these were: Teatralna, Złoty Ul, Ekspres, Bałtycka, Alga, Marago, Madras, Turystyczna, Morska), as well as known drug dens. During the operation, names of a dozen or so people connected to drugs or prescriptive medication were established. Interestingly, only one person was found to possess "three types of white powder", which were confiscated. The operation was performed again in August 1972, but also with little success. The results of both operations, conducted by law enforcement agencies without sparing costs, in spring and summer seasons, in a tourist destination and the entertainment center of the region, may suggest that the problem of drug use was not that common in Pomerania in the early 1970s. 
The biggest drug markets were - according to the report quoted - Asia, Western Europe, and North and South America. Furthermore, Asia and America were the biggest drug manufacturers [Latka A. 1990: 17-18].

Although at the time communist Poland remained more of a transit country, through which drugs were transported to Western Europe from Afghanistan, India, Pakistan or western African countries, the "Wiadomości Celne ("Customs News") magazine reported in 1989 that in the previous three years several smuggle attempts were detected and stopped (e.g. $8.5 \mathrm{~kg}$ of cannabis at the Warsaw airport, 205 grams of amphetamine in Świnoujście, $2.5 \mathrm{~kg}$ of heroin on a Warsaw-Belgrade train and - overall - around $70 \mathrm{~kg}$ of heroin on Polish merchant ships). In the 1980s, drugs were smuggled mainly on merchant ships, by air mail or by sea freight. The detection rate of drug smuggle in Poland was not impressive. As Antoni Latka from the Main Customs Office claimed:

[...] we detect merely $10 \%$ of the actual volume of this business. And it is not just us, the situation is similar e.g. in West Germany. The number of heroin addicts is estimated at 50,000 people there. Annually, they need around 2.5 tons of the drug to feed the habit. At the same time, in the whole 1987, German customs officers detained just 198 $\mathrm{kg}$ of heroin on border crossings [Sitek E. 1989: 20-21]. ${ }^{2}$

Regardless of the type of product smuggled (be it food, gold or drugs), a means of transport was needed - marine, overland or aerial. In the 1980s, ships were the safest, most spacious, and most commonly used means of transport for smugglers. Furthermore, the marine border (i.e. ports on the eastern side of the Iron Curtain) was the least controlled connection point with the capitalist world. Another revolution in the world of smuggling, discussed here, is the illegal trade in western cars, which flooded communist Poland in the 1980s. From the moment organized autogangs (i.e. groups of car smugglers) were born, the smuggled objects could (contrary to gold or food) be simultaneously used as the means of smuggle.

${ }^{2}$ Apart from trafficking drugs to Poland, in the 1980s, one more problem was observed. Namely, the illegal production of amphetamine, using chemical reagents brought in from West Germany. "Wiadomości celne" informed Polish customs officers about this new challenge: [...] In 1987, Swedes confiscated around $20 \mathrm{~kg}$ of amphetamine manufactured in Poland, and in 1988, the number of confiscations was even higher. The perpetrators included Poles, including members of Polish ferry crews regularly traveling to Sweden, Denmark and West Germany. 


\section{FROM THE “SMALL FIAT” TO AUDI}

Organized car crime became the subject of analyses performed by the Polish Ministry of Domestic Affairs officers as early as the late 1970s. In his master's thesis from 1980, a student from the College of Domestic Affairs, Lt. Janusz Jastrzębski observed that:

[...] the growth in this category of crimes is proportional or even higher than the quantitative increase in privately owned cars [Jastrzębski J. 1980: 4].

Jastrzębski analyzed 11 criminal groups operating in the 1970s in the capital region, each comprising between 3 and 15 members. In total, criminals stole 138 cars - mainly of Polish production (Fiat 125p and 126p, Warszawa, Syrena and Żuk). The length of operation varied from a few months to 4 years, and the area of operation was limited to Poland [Jastrzębski J. 1980].

In the 1970s, in Warsaw car gangs, a distribution of roles characteristic for organized criminal groups could be observed - gang members had their "specialties", and they closely cooperated with car garages, Citizens' Militia officers and corrupt officials. Lt. Jastrzębski described e.g. a gang of 14 people stealing Fiats $125 \mathrm{p}$ and working according to these principles, operating in Warsaw in the years 1975-1978. However, in comparison with the 1980s, the methods of stealing cars remained amateurish. According to the information gathered by the Citizens' Militia, cars were only stolen by unlocking the car door with a stolen or forged key, unlocking the door with other tools (wires, high temperature), or by breaking the window. After that, the engine was started by short circuiting the wires, which concluded the theft. In the second phase, the car was made over in a "friendly" car garage and then sold to a new owner. All this - the theft methods, the standard of the cars stolen in the 1970s, the area of operation of the groups described (only Poland), and a high detection rate (including punishment for the criminals) - meant that a period of prosperity for car thieves only came in the 1980s, when the criminals operated in almost entire Europe.

The gang of "Nikoś" (Nikodem Skotarczak) from the Tricity is considered the first professional organized criminal group from the 1980s, known to historians. Their activity mainly involved stealing and trafficking western cars [Nawrocki K. no date]. Owing to support from Citizens' Militia officers, a group of people who smuggled and sold rationed products in Poland transformed, in the early 1980s, into an organized group of 
car thieves. "Nikoś" was the boss of the gang, while Tadeusz Jędrzejczak, a Citizens' Militia officer, was responsible for legalizing and selling the cars. He cooperated closely with major Waldemar Gruszczyński, the head of the criminal department of MUSW (Municipal Domestic Affairs Office) in Gdańsk. This relationship meant that (as we can read in operational files):

[...] Jędrzejczak used some Citizens' Militia officers to import stolen cars in their names or to transport these cars from border crossing points [AIPN Gdańsk, WUSW Gdańsk, 0046/689, vol. 1, f. 40].

The Pomeranian market of stolen cars in the first half of the 1980s was supplied from West Germany, Belgium and France. Thieves stole primarily Audi, Volkswagen, Mercedes and Peugeot cars. Gangs used several techniques, the dominating one being the "tank cap method": stealing the keylocked cap for the car's fuel tank and forging the key, as the same key usually opened the car door. Using the forged key, the thieves could steal the car whenever it was most convenient for them. Less sophisticated methods included the "classic method" of forcing the car door lock or breaking the window and starting the car by short circuiting the ignition wires. As to thieves operating in France, they generally (but not always) used the safest car theft method, the so-called "insurance method". The whole "theft" was organized with the help of the "victim" who sold the car at a good price to the Polish dealers. They then took the car to West Germany, and the owner received compensation for a reported "theft". Then, the car was received by Polish couriers in Aachen, having already forged car documents. Upon coming to Poland, the car with the forged documents was registered at the town council by "straw men" (uninvolved persons who acted as owners and received approx. 30,000 PLN for that service). Next, after the necessary modifications in a car garage had been performed ${ }^{3}$, the car was sold under a legal contract. Another method for stealing cars was crossing the Polish border in a car that had been legally rented from a foreign car rental company. The recipients of these cars included state security officers, private entrepreneurs, clergymen, athletes and prominent Polish United Workers' Party members (including the Gdańsk region gov-

${ }^{3}$ One of the first things that had to be done with a stolen car was changing its official manufacture year, color, locks, putting on stickers, and rewinding the meter. This way the quality of the car was "improved", and therefore the selling price was higher. This task was performed by select "friendly" car garages. 
ernor, gen. Mieczysław Cygan, and the secretary of the PUWP Municipal Committee executive in Sopot, Henryk Konkol) [AIPN Gdańsk, WUSW Gdańsk, 0046/689, vol. 2, f. 68; vol. 3, f. 37; vol.1, f. 201].

From April to November 1984 only, the group lead by Skotarczak imported to Poland and sold around 80 western cars (at least this is what the investigators managed to establish). At the same time, the gang seized the opportunity and trafficked many other goods such as sweets, citrus fruits, and western clothing, just to name a few. All this - as estimated by cpt. Jan Protasewicz from the State Security Office in Gdańsk - earned the smugglers 200 million PLN in 6 months [AIPN Gdańsk, WUSW Gdańsk, 0046/689, vol. 2, f. 112]. ${ }^{4}$

The gang was finally denunciated by a State Security Office secret collaborator. On December 22, 1984, criminal and fiscal proceedings were initiated against Nikoś. He was suspected of smuggling 198 pairs of jeans and 27 video tapes of a total value of 1,125,000 PLN [AIPN Gdańsk, WUSW Gdańsk, 0046/689, vol. 2, f. 201]. Skotarczak was restricted from leaving Poland [AIPN Gdańsk, EAGD, 114475, f. 133]. Furthermore, due to the fact that Citizens' Militia officers were involved in the business, the Gdańsk division of the Officers Protection Office (IOF) became interested in the case, launching an operation code-named "Gruda" [AIPN Gdańsk, WUSW Gdańsk, 0046/689, vol.1, f. 39]. The investigation launched by the District Prosecutor's Office in Gdańsk (and performed by the MUSW Investigation Department in Gdańsk) brought no spectacular results. As we could read in the files:

Despite investigating the case for almost a year, the procedural situation of this inves-
tigation was unfavorable. IOF made a request to the head of WUSW in Gdansk for the
WUSW Investigation Department to take over the investigation with supervision from
the Regional Prosecutor's Office. The Regional Prosecutor's Office launched the inves-
tigation on October 25, 1985. It concerned a criminal group operating from 1983 [AIPN
Gdańsk, SW (Regional Court) Gdańsk, 98/1, vol. 1, f. 56].

During the investigation, the following people were arrested and charged: Sławomir Bielakowski, Henryk Konopka, Edwin Myszek, Wiesław Pniewski, Jerzy Serowski, Tadeusz Jędrzejczak and others. The investigation led by the Regional Prosecutor's Office established that the main suspect was Nikodem Skotarczak (suspected of stealing and trafficking

${ }^{4}$ Back then the average annual salary was slightly above PLN 202,000 (12 x 16,838). 
cars) [AIPN Gdańsk, WUSW Gdańsk, 0046/689, vol. 1, ff. 40-41]. The car business was possible owing to successful cooperation between the gang and a customs officer from the Kołbaskowo border crossing point, Marek Biernat [AIPN Gdańsk, SW Gdańsk, 98/1, f. 297 et seq.]. ${ }^{6}$ Edwin Myszek testified: "Nikodem Skotarczak bragged that they have their own customs officer, called Marek" [AIPN Gdańsk, SW Gdańsk, 98/1, vol. 1, f. 185]. Just like the rest of those engaged in stealing and smuggling cars, Marek Biernat was also arrested in late 1985 [AIPN Gdańsk, SW Gdańsk, 98/1, f. 235]. Only the formal boss of the group, "Nikoś," remained at large, and in the fall of 1985 [Rixdorf W. 1993: 22], despite being forbidden from leaving the country, managed to escape to West Germany.

\section{“AUTOGANGS"}

In the second half of the 1980s, there were at least a few organized criminal groups engaged in wholesale car theft and traffic, operating in Western Europe. In the operational and investigative files on the bosses of "autogangs", the following names are mentioned: Bogusław Barcz (operating in Austria), Bogusław Chmielewski, Zdzisław Jakubiec and Władysław Rembecki (Austria, West Germany), Josef Hoffman (the whole Western Europe), Andrzej Striegler and Grzegorz Stusiński (the whole Western Europe), and Jacek and Leszek Żelazik (France, West Germany, Sweden, USA) [AIPN BU, SUSW, 01205/226, vol. 1, f. 90]. One of the gangs that operated the longest and brought biggest profits was the one led by Jan Labut,

${ }^{5}$ In the investigation by the Regional Prosecutor's Office, there were 50 suspects, and 35 cars stolen from West Germany, Sweden and France were secured. 98 cars were tested. The amnesty act $(1989$ - KN) led to discontinuation of the investigation concerning "the stealing of cars abroad and their import to Poland. The act covered all the members of the group (except for the Citizens' Militia officers - KN). They were also spared the additional punishment (fines). The investigation was terminated on December 31, 1989."

${ }^{6}$ Marek Biernat had been working in the customs office for 12 years. During his cooperation with the members of the "Nikos'" gang, he was a shift manager at the Kołbaskowo border crossing point. He received several medals for his professional performance, including the medal of merit for the customs service. Biernat was also politically engaged - from 1972 he was a member of the Socialist Youth Association, the Polish-Soviet Friendship Society and the PUWP. In April 1982, he became the head of the Customs Office team in the political and defense divisions of the Regional Committee of PUWP. 
a Pole living near Vienna. ${ }^{7}$ Some of the people mentioned above were even convicted for car trafficking by the Austrian judiciary. Austrians identified 51 cars smuggled illegally to Poland. The investigation established that there were 9 people involved. They were charged with operating an organized criminal group, stealing cars in several Austrian regions in the years 1986-1987. Jan Labut was identified as the boss. At that time, he had already been put into custody in Poland [AIPN BU, SUSW, 01205/226, vol. 2, ff. 16-17]. The search for Labut was no obstacle to sentencing members of the group to imprisonment [AIPN BU, SUSW, 01205/226, vol. 2, ff. 18-19].

Nikodem Skotarczak also ended up in a German prison, having moved his car-related criminal activities to West Germany after his escape from Poland. He was arrested in April 1989, and sentenced to 1 year and 9 months in prison. At that time, German press wrote about 500 stolen cars worth DEM 10 million (German marks). Police from Wiesbaden, where the German Federal Criminal Police had its headquarters, established that Skotarczak's gang was responsible for stealing around 100 cars (between June 1987 and April 1989). ${ }^{8}$ The so-called "Golf gang", which mainly stole Volkswagen Golf and Audi cars, ${ }^{9}$ had about 40 members.

In the 1980s, a typical car gang usually operated according to a fixed formula. There were thieves, couriers, and straw men, but fundamentally the division of tasks assumed the following stages: theft committed outside Poland, smuggling over borders, and then reception and legalization in Poland. The last but not least important stage of the procedure was registering the car in Poland and its further distribution. Therefore, representatives of the "reception" network complement the aforementioned list of the names of the members of car gangs operating mainly outside Poland. In Warsaw alone, if we are to believe Jan Labut, around 20 people were involved in handling stolen cars from the west [AIPN BU, SUSW, 01205/226, vol. 1, f. 90]. Similar groups operated in Kraków [AIPN BU, SUSW, 01205/226, vol. 2, ff. 177-178], Olsztyn [AIPN BU, SUSW,

7 See: Nie tylko "Nikoś". Polskie "autobandy" w końcówce lat 80. XX w., [Not just "Nikoś". Polish "autogangs" in the late 1980s] (pending publication). The chapter "Autogangs" is based on portions of that text.

${ }^{8}$ In 1987, 1530 cars were imported to Poland from West Germany (data available), and only 45 of them were considered stolen.

${ }^{9}$ A car was typically sold for DEM 18,000. The courier got DEM 400, the thief - DEM 1000, the forger who prepared a set of documents - DEM 1500, the boss - DEM 9000, and DEM 600 were spent on customs. 
01205/226, vol. 49, ff. 57-58], Bydgoszcz (from September 1984) [AIPN BU, MSW, 01549/5, vol. 3, ff. 39, 67] and Kielce [AIPN BU, MSW, 01549/5, vol. 3, f. 68].

Black market prices of the "imported" cars were between 2.5 and 3 thousand dollars (luxury cars - up to 5 thousand), while regular market prices were between 10 and even 25 thousand dollars. Thus it made sense for wealthy Poles to buy cars stolen from Western Europe (whether they were aware of their origin or not). These cars were more easily available than those distributed legally through the complicated program of prepayments, and their black market price was much lower than the official one. Furthermore, western cars were a secure investment. Section 169 of the Civil Code remained one drawback of the transaction. In the case of cars, it meant that whoever, in the period of 3 years following the theft:

[...] entered into an agreement with the owner and took over in good will the ownership of a vehicle (...), becomes the owner only after this time. During this period, the former owner can demand the car they had lost to be returned, also by a buyer who bought it in good will [...] [AIPN BU, SUSW, 01205/226, vol. 1, f. 207; http:/ / prawo.money.pl/kodeks/cywilny/dzial-iii-nabycie-i-utrata-wlasnosci/rozdzial-iprzeniesienie-wlasnosci/art-169].

Traffic in stolen cars was common and ofter problem-free for criminals, owing to the post-war "iron curtain" in Europe, the legal regulations of communist Poland, and the attitude of public officials. In the late 1980s, the problem of smuggling cars was so common and the interventions of insurance companies operating on behalf of the victims so frequent, that special regulations in this matter were issued by the most important Polish institutions: the Prosecutor's General Office and the Citizens' Militia Main Headquarters. The initial findings of the Prosecutor's General Office indicated directly that proving a car theft is a serious problem for the Polish law enforcement agencies. It was assumed that the "majority of the cars came from legitimate sources" [AIPN BU, SUSW, 01205/226, vol. 1, f. 204]. Wincenty Grzeszczyk, the deputy director of the Criminal Proceedings Department of the Prosecutor's General Office, who knew the insurance method ${ }^{10}$ of trafficking cars, wrote:

${ }^{10}$ It involved an agreement between a citizen of Western Europe, who sold a car, and a Polish "courier". Based on this agreement, the Pole bought the car at a very good price, agreeing that after some time the seller would report its theft to the local police. This meant that the seller received insurance money and the buyer (who could hardly be called a thief in this case) received a car at a very good price. 
[...] it might happen that a Polish citizen buys a vehicle from the owner based on a formal concluded contract, and then, when the car is already in Poland, the seller reports theft to the police in order to obtain compensation from the insurance company under false pretenses [AIPN BU, SUSW, 01205/226, vol. f. 205].

This means that the possibilities to pursue investigations were limited because the car could be confiscated as evidence of crime only after pre-trial proceedings were launched. This required proving that the car had been stolen and not obtained as a result of a deal between a "victim" from the West and a "thief" from the East. The Citizens' Militia Main Headquarters was also unable to handle this new trend in smuggling. In January 1989, an officer from the Main Headquarters, Lt Col. Aleksander Pontus wrote:

[...] traffic in Western cars is the result of imperfections in customs and registration provisions and of the absorbent nature of the Polish market and of the number of people recruited in the West [AIPN BU, SUSW, 01205/226, vol. 1, f. 209].

The problem was discussed in a similar tone a month later, in an official letter on the methods of fighting with car gangs:

[...] Last year, we saw an increase in imports of cars to Poland, some of which were stolen and then easily sold to the legal market, due to the simplified procedure of registration. This brought a number of legal and criminal problems resulting mainly from the lack of consistent rules of proceeding in those cases [AIPN BU, SUSW, 01205/226, vol. 1, f. 127].

\section{AFTERWORD}

An attempt to statistically calculate the scale of criminal proceedings is always burdened with a high error rate. One has to be aware that all the data either refer solely to goods recovered by law enforcement agencies or are only estimates established during operational activities. Organized, professional criminal groups do all they can to minimize the availability of data concerning their actions, regardless of the time they operate in. This means that criminal statistics, both in the case of smuggled cars and of other goods, remain only the estimates of law enforcement agencies. However, even the estimated data concerning car crime in the last decade of communist Poland are food for thought.

As it was mentioned, according to the calculations by captain Jan Protasewicz from the State Security Office in Gdańsk, in just 6 months 
in 1984, the gang led by "Nikoś" made an impressive 200 million PLN [AIPN Gdańsk, WUSW Gdańsk, 0046/689, vol. 2. f. 112]. While working on "Labut's gang", the investigators estimated that in Poland:

[...] mostly in Warsaw, at least 1,000 cars stolen from capitalist countries were registered [AIPN BU, SUSW, 01205/226, vol. 1, ff. 79-85].

As we can calculate, the 1000 [AIPN BU, SUSW, 01205/226, vol.1, ff. 88] ${ }^{11}$ of imported cars at, let us assume, 3,000 dollars each, equals 3 million dollars, i.e over one billion Polish zloty [http://stat.gov.pl/obszary-tematyczne/ rynek-pracy/pracujacy-zatrudnieni-wynagrodzenia-koszty-pracy/prze cietne-miesieczne-wynagrodzenie-w-gospodarce-narodowej-w-latach1950-2015,2,1.html]. ${ }^{12}$ Similar calculations, without pointing to the exact number of cars stolen, were performed in May 1989 by the deputy head of the SUSW investigation department, captain Mieczysław Chyłkiewicz. He claimed that 17 people suspected of stealing cars from the West caused losses of:

[...] 1 billion zloty, out of which 300 million PLN was reclaimed, and goods worth 300 million PLN were secured [AIPN BU, SISW, 01205/226, vol. 1, f. 146].

This means that the illegal car business in the late communist period in Poland was very lucrative. At the same time the profit - as the previous chapter attempted to demonstrate - did not require taking much of a risk. Legal, customs and technical conditions made it practically impossible for the law enforcement agencies to fight car crime. Statistical analyses made by Hubert Wilk [Wilk H. 2015: 170], who established that in the 1980s, 337 thousand cars purchased outside of the legal distribution channels could be found in the Polish roads, encourages us to reflect upon one more problem [Wilk H. 2015: 179]. ${ }^{13}$ These were - as one can assume - both foreign and domestic cars, not just stolen, but also sold and purchased without

11 In the annex made in April 1989 to "The general action plan..." it was established that a court would be able to prove the theft of "only" 200 cars registered in the Warsaw region alone.

12 An average monthly salary in the national economy in 1987 was PLN 29,184, in 1988 - PLN 53,090 and in 1989 - PLN 206,758.

${ }^{13}$ Hubert Wilk gives the number of 447 thousand, which seems erroneous taking into consideration his previous calculations. The volume of production was 2.650 million $+\mathrm{im}-$ ports 0.384 million - exports 0.858 million $=0.337$ million, not 0.437 . Therefore, it seems justified to say that in the Polish roads, there were 337 thousand cars bought outside of the official distribution channels. 
complying with all the procedures. The status of this number is definitely not clear-cut. This does not change the fact that the abovementioned number - 1000 stolen cars - only accounted for a small percentage of this criminal business. The business was not actually fought with by any national institution in the last years of communist Poland, and - because of the amnesty act of December 1989 - it was never actually punished.

\section{BIBLIOGRAPHY}

\section{ARCHIVE MATERIALS}

The Archive of the Institute of National Remembrance in Gdańsk (AIPN Gdańsk) - Regional Domestic Affairs Office Gdańsk (WUSW Gdańsk).

AIPN Gdańsk - Regional Citizens' Militia Headquarters (KW MO Gdańsk).

AIPN Gdańsk - EAGD.

AIPN Gdańsk - Regional Court in Gdańsk (SW Gdańsk).

AIPN BU - Capital Domestic Affairs Office (SUSW).

AIPN Gdańsk - WUSW Gdańsk, sign. 0087/34, vol. 17.

AIPN Gdańsk - KW MO Gdańsk, sign. 0046/258, Report on the "Mak" operation, May 30, 1972, f. 98; Report, July 11, 1972, f. 108.

AIPN Gdańsk - WUSW Gdańsk, sign. 0046/689, vol. 1, Request of IOF to terminate the “Gruda" operation - January 31, 1990, f. 40.

AIPN Gdańsk - WUSW Gdańsk, sign. 0046/689, vol. 2, Findings of the investigation on a criminal group operating in Gdańsk and Warsaw, September 29, 1984, f. 68.

AIPN Gdańsk - WUSW Gdańsk, sign. 0046/689, vol. 3, Report from interrogation of Henryk Konkol, March 26, 1983, f. 37. AIPN Gdańsk - WUSW Gdańsk, sign. 0046/689, vol. 1, Information from the Head of WUSW Department III in Gdańsk, February 21, 1985, f. 201.

AIPN Gdańsk - WUSW Gdańsk, sign. 0046/689, vol. 2, Findings of the investigation on a criminal group operating in Gdańsk and Warsaw, September 29, 1984, f. 112.

AIPN Gdańsk - WUSW Gdańsk, sign. 0046/689, Information from the Head of WUSW Department III in Gdańsk, February 21, 1985, f. 201.

AIPN Gdańsk - EAGD, sign. 114475, Prohibition to leave the country, April 1985, f. 133.

AIPN Gdańsk - WUSW Gdańsk, sign. 0046/689, vol. 1, Request of IOF to terminate the "Gruda" operation - January 31, 1990, f. 39.

AIPN Gdańsk - SW Gdańsk, sign. 98/1, vol. 1, The decision to launch the investigation, October 24, 1985, f. 56.

AIPN Gdańsk - WUSW Gdańsk, sign. 0046/689, vol. 1, Request of IOF to terminate the "Gruda" operation - January 31, 1990, f. 39.

AIPN Gdańsk - WUSW Gdańsk, sign. 0046/689, vol. 1, The request of IOF to terminate the "Gruda" operation - January 31, 1990, f. 40; ibidem, f. 41.

AIPN Gdańsk - SW Gdańsk, sign. 98/1, vol. 1, A questionnaire of Customs Office in Szczecin, January 2, 1986, f. 297 et seq.

AIPN Gdańsk - SW Gdańsk, 98/1, vol. 1, The decision to press charges against Marek Biernat, December 14, 1985, f. 235. 
AIPN BU - SUSW, sign. 01205/226, vol. 1, An annex to the general plan of operational and investigative activities in the case of purchasing stolen cars in Western Europe and importing them to Poland, April 7, 1989, f. 90.

AIPN BU - SUSW, sign. 01205/226, vol. 2, A letter from the Austrian criminal court in Vienna to the Regional Prosecutor's Office in Warsaw [1989], ff. 16, 17.

AIPN BU - SUSW, sign. 01205/226, vol. 2, ff. 18, 19.

AIPN BU - SUSW, sign. 01205/226, vol. 1, An annex to the general plan of operational and investigative activities in the case of purchasing stolen cars in Western Europe and importing them to Poland, April 7, 1989, f. 90.

AIPN BU - SUSW, sign. 01205/226, vol. 2, A memo of a senior superintendent of the WUSW Criminal Department in Kraków Lt. M. Kłosowski, June 27, 1989, ff. 177, 178; ibidem, vol. 3, A notification sent from SUSW to Department I of the Investigation Bureau of the Ministry of Domestic Affairs, November 13, 1989, f. 335.

AIPN BU - SUSW, sign. 01205/226, vol. 49, A memo of superintendent Leszek Lewiński, November 3, 1988, ff. 57, 58.

AIPN BU - Ministry of Domestic Affairs, sign. 01549/5, vol. 3, A memo, July 26, 1988, f. 39; ibidem, A report from the stay in WUSW in Bydgoszcz, August 12, 1988, f. 67.

AIPN BU - MSW, sign. 01549/5, vol. 3, A report from the stay in WUSW in Bydgoszcz, August 12, 1988, f. 68.

AIPN BU - SUSW, sign. 01205/226, vol. 1, Rules (sent by Prosecutor's General Office - KN) for launching preparatory proceedings in cases concerning imports of stolen or appropriated cars to Poland and for using these as evidence, December 23, 1988, f. 207;

AIPN BU - SUSW, sign. 01205/226, vol. 1, Rules (sent by Prosecutor's General Office - KN) for launching preparatory proceedings in cases concerning imports of stolen or appropriated cars to Poland and for using these as evidence, December 23, 1988, f. 204

AIPN BU - SUSW, sign. 01205/226, vol. 1, Rules (sent by Prosecutor's General Office - KN) for launching preparatory proceedings in cases concerning imports of stolen or appropriated cars to Poland and for using these as evidence, December 23, 1988, f. 205

AIPN BU - SUSW, sign. 01205/226, vol. 1, A memo of Citizens' Militia Main Headquarters, Department II, Investigation Bureau specialist, Lt Col. A. Pontus, January 10, 1989, f. 209.

AIPN BU - SUSW, sign. 01205/226, vol. 1, A letter from Citizens' Militia Main Headquarters to the deputy head of SUSW on Militia, February 3, 1989, f. 127.

AIPN Gdańsk - WUSW Gdańsk, 0046/689, vol. 2, Findings from investigation concerning a criminal group operating in Warsaw and Gdańsk, November 29, 1984, f. 112.

AIPN BU - SUSW, sign. 01205/226, vol. 1, The general plan of operational and investigative activities in the case of purchasing stolen cars in Western Europe and importing them to Poland, August 16, 1988, ff. 79-85.

AIPN BU - SUSW, sign. 01205/226, vol. 1, An annex to the general plan of operational and investigative activities in the case of purchasing stolen cars in Western Europe and importing them to Poland, April 7, 1989, f. 88.

AIPN BU - SUSW, sign. 01205/226, vol. 1, ff 146, A notification on launching proceedings sent from SUSW to the Inspection Division of the Investigation Bureau of the Ministry of Domestic Affairs, May 31, 1989, f. 146.

\section{LITERATURE}

Jastrzębski J. (1980), Kradzieże samochodów przez zorganizowane grupy przestępcze [Car theft by organized criminal groups], a Master's thesis supervised by Lt. Eugeniusz Kędra, Warsaw, in: AIPN BU, 1510/4339. 
Kochanowski J. (2010), Tylnymi drzwiami. "Czarny rynek” w Polsce 1944-1989 [Through the back door. Black market in Poland 1944-1989], Warsaw.

Latka A. (1983), Przemyt na barkach międzynarodowej żeglugi śródladowej [Smuggle using the barges of the international inland shipping] "Wiadomości Celne" no. 42-43.

Latka A. (1990), Przemyt narkotyków [Drug trafficking] “Wiadomości Celne”, no. 49-50, I-VI 1990.

Nie tylko "Nikoś". Polskie „autobandy" w końcówce lat 80. XX w., [Not just "Nikoś". Polish "autogangs" in the late 1980s] (pending publication).

Nawrocki K. (no date), Mafia w peerelowskim wydaniu. Milicjanci w strukturze gangu "Nikosia" [Mafia in communist Poland. Citizen's Militia officers in the "Nikoś" gang] [pending publication].

Nawrocki K. (no date), Milicjanci i złodzieje, [Citizen's Militia officers and thieves] [pending publication].

Rixdorf W. (1993), Das steinerne Gesicht: Der Pate von Danzig Nikodem Skotarczak (A straight face: Nikodem Skotarczak, the Godfather from Gdansk), Berlin.

Sitek E. (1989), Biała śmierć w Polsce [“White death" in Poland], „Wiadomości Celne”, no. 47-48, VIII-XII 1989.

Wilk H. (2015), Zmotoryzowane lata osiemdziesiate [Motorized 1980s] [in:] Jarska N., Olaszek J., „Społeczeństwo polskie w latach 1980-1989”, [Polish society in the years 19801989], Warsaw.

http:// prawo.money.pl/kodeks/cywilny/dzial-iii-nabycie-i-utrata-wlasnosci/rozdziali-przeniesienie-wlasnosci/art-169 [accessed July 10, 2016].

http:/ / stat.gov.pl/obszary-tematyczne/rynek-pracy/pracujacy-zatrudnieni-wyna grodzenia-koszty-pracy/przecietne-miesieczne-wynagrodzenie-w-gospodarce-naro dowej-w-latach-1950-2015,2,1.html [accessed April 30, 2016].

Karol Nawrocki - PhD, graduated master and doctoral studies at the University of Gdańsk, Head of the National Education Office of the Institute of National Remembrance in Gdańsk. His scientific interest include organized crime problems in Polish "People's" Republic, history of sport and history of anti-communist opposition. 
